\title{
Analisis Kemampuan Guru Melaksanakan Pembelajaran Tematik Terintegrasi Pendidikan Karakter
}

\author{
Komang Sujendra Diputra ${ }^{1^{*}}$, I Gusti Ngurah Japa ${ }^{2}$ \\ ${ }^{12}$ Jurusan Pendidikan Guru Sekolah Dasar, Universitas Pendidikan Ganesha, Indonesia
}

\section{A R T I CLEINFO \\ Article history: \\ Received 18 Desember 2017 \\ Received in revised form 30 Desember 2017 \\ Accepted 15 Januari 2018 \\ Available online 20 \\ Februari 2018}

Kata Kunci :

Karakter, Tematik

Kurikulum 2013

Keywords:

Character, Curriculum 2013,

Thematic

\begin{abstract}
A B S T R A K
Penelitian ini bertujuan untuk mendeskripsikan kemampuan guru dalam melaksanakan pembelajaran tematik Kurikulum 2013 pendidikan karakter terpadu, oleh karena itu penelitian ini adalah penelitian deskriptif. Data yang dihasilkan adalah 1) pemahaman guru tentang konsep pendidikan karakter, 2) skor RPP yang dirancang oleh guru, dan 3) skor pelaksanaan pembelajaran guru. Pengumpulan data dilakukan dengan wawancara, kuesioner, observasi, dan dokumentasi. Hasil penelitian menunjukkan bahwa guru telah memahami konsep pendidikan karakter tetapi belum secara detail terkait dengan deskripsi 18 nilai karakter yang dapat dikembangkan dalam pembelajaran. Sehubungan dengan pelajaran kurikulum yang diusulkan Kurikulum 2013, nilai-nilai karakter yang dipilih untuk dikembangkan dalam pelajaran belum terlihat dalam langkah-langkah pembelajaran. Dalam tahap pelaksanaan pembelajaran, nilai karakter yang tercantum dalam RPP belum diimplementasikan dengan benar.
\end{abstract}

This study aims to describe the ability of teachers in implementing thematic learning Curriculum 2013 integrated character education, therefore this research is a descriptive research. The data generated are 1) the teacher's understanding of the conception of character education, 2) the RPP score designed by the teacher, and 3) the teacher learning implementation score. Data collection is done by interview, questionnaire, observation, and documentation. The results showed that the teacher has understood the conception of character education but not yet in detail related to the description of 18 character values that can be developed in the learning. In relation to the proposed curriculum lesson of the 2013 Curriculum, the character values chosen to be developed in the lesson have not been seen in the learning steps. In the implementation stage of learning, the character values listed in the RPP have not been implemented properly.

\footnotetext{
1 Corresponding author.

E-mail addresses: sujendra@undiksha.ac.id
} 


\section{Pendahuluan}

Pendidikan memegang peranan penting dalam proses peningkatan kualitas sumber daya manusia. Menurut UU No 20 Tahun 2003 pendidikan nasional berfungsi mengembangkan kemampuan dan membentuk watak serta peradaban bangsa yang bermartabat dalam rangka mencerdaskan kehidupan bangsa, bertujuan untuk berkembangnya potensi peserta didik agar menjadi manusia yang beriman dan bertakwa kepada Tuhan Yang Maha Esa, berakhlak mulia, sehat, berilmu, cakap, kreatif, mandiri, dan menjadi warga negara yang demokratis serta bertanggung jawab. Hal tersebut menunjukkan bahwa sistem pendidikan nasional harus mampu mengembangkan kemampuan dan membentuk karakter peserta didik.

Pentingnya karakter juga tercermin dari hasil penelitian di Harvard University Amerika Serikat yang memaparkan bahwa kesuksesan hidup seseorang tidak sepenuhnya ditentukan oleh pengetahuan dan kemampuan teknis (hard skill) yang diperoleh lewat pendidikan, tetapi lebih oleh kemampuan mengelola diri yang di dalamnya termasuk karakter dan orang lain (soft skill). Bahkan orang-orang tersukses di dunia bisa berhasil dikarenakan lebih banyak didukung kemampuan soft skill dibandingkan hard skill (Adisusilo, 2011).

Pemerintah telah menyikapi pendidikan karakter ini dengan memberlakukan Kurikulum 2013 dengan karakteristik utamanya adalah pemberlakuan pembelajaran tematik integratif di sekolah dasar. Pembelajaran tematik integratif (terpadu) merupakan salah satu model pembelajaran terpadu yang menggunakan tema untuk mengaitkan beberapa mata pelajaran sehingga dapat memberikan pengalaman bermakna bagi peserta didik. Pembelajaran terpadu didefinisikan sebagai pembelajaran yang menghubungkan berbagai gagasan, konsep, keterampilan, sikap, dan nilai, baik antar mata pelajaran maupun dalam satu mata pelajaran (Permendikbud No. 57, 2014). Pembelajaran Tematik Kurikulum 2013 memiliki pendekatan yang berbeda dengan pembelajaran tematik pada kurikulum sebelumnya. Pendekatan yang digunakan untuk mengintegrasikan Kompetensi Dasar dari berbagai mata pelajaran yaitu intradisipliner, interdisipliner, multidisipliner, dan transdisipliner.

Standar kompetensi lulusan dalam Kurikulum 2013 mengharuskan kualitas lulusan baik di tingkat sekolah dasar memiliki kemampuan yang mencakup sikap, keterampilan, dan pengetahuan. Hal ini mengindikasikan bahwa pendidikan karakter harus ada dalam pembelajaran untuk menunjang kualitas peserta didik yang dihasilkan. Terkait pelaksanaan pendidikan karakter di sekolah, selama ini proses pembentukan karakter siswa dianggap sebagai tanggung jawab guru agama, pendidikan kewarganegaraan, maupun guru bimbingan konseling (Hadi, 2015). Seharusnya pendidikan karakter merupakan tanggung jawab semua guru yang bisa dilakukan dengan mengintegrasikan nilai karakter dalam setiap pembelajaran.

Secara etimologi, istilah karakter diambil dari bahasa Yunani, yaitu kharakter, kharassein, and kharax yang artinya suatu alat untuk menandai (El-Mubaroq, 2008). Pendidikan karakter dapat didefinisikan sebagai jenis pendidikan yang bertujuan untuk membina perilaku dan kepribadian melalui pendidikan moral dan etika. Kementerian Pendidikan Nasional (2010) mengidentifikasi delapan belas nilai karakter yang perlu diintegrasikan dalam pembelajaran yaitu: (1) Religius, (2) Jujur, (3) Toleransi, (4) Disiplin, (5) Kerja keras, (6) Kreatif, (7) Mandiri, (8) Demokratis, (9) Rasa Ingin Tahu, (10) Semangat Kebangsaan, (11) Cinta Tanah Air, (12) Menghargai Prestasi, (13) Bersahabat/Komunikatif, (14) Cinta Damai, (15) Gemar Membaca, (16) Peduli Lingkungan, (17) Peduli Sosial, dan (18) Tanggung Jawab.

Para guru diharapkan memilih nilai-nilai karakter yang cocok dengan kompetensi dasar yang diajarkan. Namun kenyataannya, guru masih terlihat ragu untuk memasukkan variabel karakter ke dalam rencana pembelajaran mereka susun yang disebabkan tidak adanya pedoman atau standarisasi bagaimana mengintegrasikan nilai karakter ke dalam pembelajaran. Hal yang sama terjadi pada GuruGuru SD di Kecamatan Sukasada. Berdasarkan hasil observasi yang telah dilakukan, ternyata walaupun rata-rata SD di Kecamatan Sukasada telah menerapkan pendidikan karakter dalam pembelajaran, namun pendidikan karakter tersebut tidak terintegrasi secara baik dan menyeluruh dalam perangkat pembelajaran yang digunakan, sehingga implementasi pendidikan karakter dalam proses pembelajarannya tidak tampak (Japa \& Diputra, 2016).

Berdasarkan wawancara dengan Kepala UPP Kecamatan Sukasada ditemukan bahwa kepala sekolah masih kurang dalam melakukan pengawasan terhadap guru dalam melaksanakan pembelajaran berbasis karakter. Pengawasan masih terbatas pada kehadiran guru di kelas tanpa memperhatikan kualitas pembelajaran yang dilakukan. Hal ini beralasan mengingat pengetahuan dan wawasan dari kepala sekolah maupun guru-guru binaannya terkait pendidikan karakter dan implementasinya dalam pembelajaran yang masih kurang mendalam. 
Berdasarkan pemaparan di atas tentang pentingnya nilai karakter di era global, sudah seharusnya pendidikan karakter mendapatkan porsi yang sama dalam pembelajaran khususnya pembelajaran tematik integratif. Pendidikan karakter mulai direncanakan dari tahap persiapan (penyusunan RPP) sampai ke tahap implementasinya. Oleh karena itu sangat perlu dilakukan kajian yang mendalam mengenai bagaimana kemampuan guru melaksanakan pembelajaran karakter khususnya dalam pembelajaran tematik kurikulum 2013 baik dalam perangkat pembelajaran maupun implementasinya.Hal ini akan menjadi landasan dalam perumusuan langkah-langkah maupun kebijakan untuk menghasilkan pembelajaran tematik yang berkualitas sesuai tuntutan kurikulum.

\section{Metode}

Penelitian ini bertujuan untuk mendeskripsikan kemampuan guru dalam melaksanakan pembelajaran tematik Kurikulum 2013 terintegrasi pendidikan karakter, oleh karena itu penelitian ini merupakan penelitian deskriptif. Secara rinci, data yang dihasilkan adalah 1) pemahaman guru terhadap konsepsi pendidikan karakter, 2) skor RPP yang dirancang guru, dan 3) skor pelaksanaan pembelajaran yang dilakukan guru. Subjek penelitian ini adalah Guru Kelas IV SD di Gugus III dan IV Kecamatan Sukasada Kabupaten Buleleng Propinsi Bali yang tersebar di 12 sekolah yaitu SD N 1 Silangjana, SD N 2 Silangjana, SD N 2 Pegadungan, SD N 3 Pegadungan, SD N 1 Padang Bulia, SD N 2 Padang Bulia, SD N 1 Sukasada, SD N 2 Sukasada, SD N 3 Sukasada, SD N 4 Sukasada, SD N 5 Sukasada, dan SD N 1 Ambengan.

Pengumpulan data dilakukan dengan cara yaitu a) Wawancara mendalam dengan guru mata pelajaran Kelas IV SD di Gugus III dan IV Kecamatan Sukasada, b) Angket yang diberikan kepada guru dengan tujuan untuk memperoleh terkait pemahaman guru mata pelajaran Kelas IV SD di Gugus III dan IV Kecamatan Sukasada tehadap pemahaman pembelajaran tematik integratif Kurikulum 2013, c)Observasi, yang dilakukan di kelas untuk mendapatkan data tentang kemampuan guru dalam mengembangkan pendidikan karakter dalam pembelajaran, dan nilai-nilai karakter yang dimuculkan siswa dalam pembelajaran, dan d) Dokumentasi yaitu mengumpulkan data tentang kurikulum, Silabus, dan RPP yang dibuat guru mata pelajaran Kelas IV SD di Gugus III dan IV Kecamatan Sukasada yang selanjutnya dianalisis untuk mendapatkan deskripsi pembelajaran yang dilakukan selama ini di sekolah masingmasing. Pedoman wawancara dan angket untuk perekaman data penelitian menggunakan instrumen yang dikembangkan peneliti yang sebelumnya divalidasi secara isi oleh pakar evaluasi pembelajaran di Universitas Pendidikan Ganesha.

\section{Hasil dan Pembahasan}

Kuesioner diberikan kepada Guru Kelas IV dan untuk menggali keterangan lebih lanjut dilakukan dengan metode wawancara. Secara rinci rekapitulasi hasil isian kuesioner diikhtisarkan pada Tabel 1 berikut

Tabel1. Rekapitulasi Kuesioner Guru

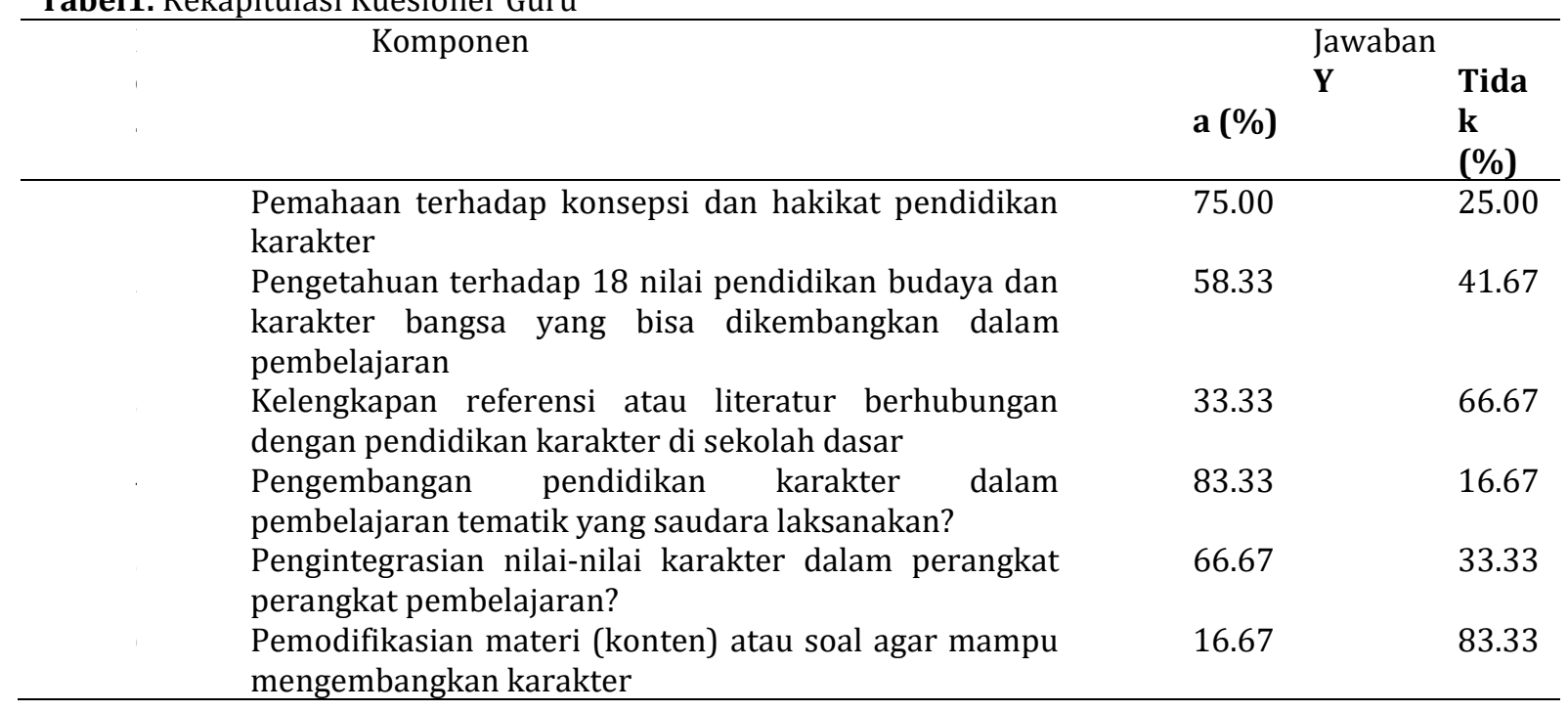

Berdasarkan Tabel 1, Guru-guru SD di Gugus III dan IV Kecamatan Sukasada sudah memahami pendidikan karakter dan sudah berupaya mengintegrasikan nilai-nilai karakter dalam perangkat 
pembelajaran. Komponen (3) dan (4) menunjukkan bahwa guru belum memaksimalkan materi-materi atau soal-soal dalam pembelajaran dalam pengembangan karakter, dan juga kurangnya referensi atau buku yang memberikan penjelasan atau penambah wawasan terkait pelaksanaan pendidikan karakter dalam muatan mata pelajaran.

Rekapitulasi Hasil Penilaian RPP Guru

Penilaian RPP dilakukan oleh tim peneliti yang secara rinci dipaparkan pada Tabel 2 berikut.

Tabel 2. Rekapitulasi Skor RPP 12 Orang Guru

\begin{tabular}{llll}
\hline No. & Komponen RPP & Skor & Kategori \\
1. & Perumusan indikator dan tujuan pembelajaran mencakup nilai- & 18.58 & Kurang \\
& nilai karakter yang diharapkan & 16.75 & Cukup \\
2. & Pemilihan dan pengorganisasian materi ajar & 13.92 & Cukup \\
3. & Pemilihan Sumber belajar/media pembelajaran & 16.25 & Cukup \\
4. & Model, Metode, dan Strategi Pembelajaran & 12.50 & Kurang \\
5. & Penilaian hasil belajar & 78 & Cukup \\
\hline
\end{tabular}

Berdasarkan Tabel 2, terkait muatan nilai karakter yang dikembangkan dalam pembelajaran diperoleh skor 18.58 dan berada dalam kategori cukup. Dalam RPP yang dirancang sudah terdapat nilainilai karakter yang dipilih untuk dikembangkan dalam pembelajaran, akan tetapi tidak tampak di dalam kegiatan pembelajaran

Rekapitulasi Hasil Hasil Penilaian Kemampuan Guru Melaksanakan Pembelajaran

Hasil penilaian kemampuan guru melaksanakan pembelajaran terintegrasi nilai karakter yang dilakukan melalui observasi, dipaparkan pada Tabel 3 berikut.

Tabel 3. Rekapitulasi Skor Kemampuan Mengajar

\begin{tabular}{llll}
\hline No. & Aspek yang Diamati & Guru I & Guru II \\
1. & Pra pembelajaran & 8 & 8 \\
2. & Membuka pembelajaran & 7 & 7 \\
3. $\quad$ Kegiatan inti pembelajaran & 7 & 16 \\
A. Penguasaan materi pelajaran & 15 & 30 \\
B. Pendekatan/strategi pembelajaran & 30 & 16 \\
C. Pemanfaatan media pembelajaran & 16 & 25 \\
D. Pembelajaran yang memicu dan memelihara keterlibatan & 26 & \\
$\quad$ siswa & & 10 \\
E. Penilaian proses dan hasil belajar & 10 & 14 \\
F. Penggunaan bahasa & 13 & 11 \\
Penutup & 11 & 137 \\
Skor Total & 136 & \\
Skor Rata-Rata & 136.50 & \\
Pkor Maksimal Ideal & 170 & \\
\hline
\end{tabular}

Berdasarkan Tabel 3, rata-rata kemampuan guru mengajar sebesar 136.50 dengan tingkat persentase sebesar $80.30 \%$ dan berada pada kategori baik.

Hasil penelusuran melalui angket dan wawancara ditemukan bahwa guru sudah memahami konsepsi pendidikan karakter yang ditunjukkan dengan respon guru menjawab "iya" sebesar 75\%. Berdasarkan wawancara ditemukan bahwa guru mengetahui 18 nilai karakter yang bisa dikembangkan dalam pembelajaran, namun pemahaman mereka tidak terlalu mendetail terkait deskripsi masing-masing nilai karakter tersebut. Hasil identifikasi diperoleh bahwa temuan-temuan tersebut diduga disebabkan karena kurangnya referensi terkait pelaksanaan pendidikan karakter di sekolah utamanya pengintegrasian dalam muatan-muatan mata pelajaran. Hal ini juga diperkuat dengan rendahnya kesadaran untuk mengakses informasi baik yang bersifat offline dan online. 
Hasil penilaian RPP yang dirancang oleh guru terkait komponen perumusan nilai karakter dalam pembelajaran diperoleh skor 18.58 dengan persentase sebesar $61.95 \%$ yang berada dalam kategori cukup. Guru sudah memilih dan mencamtumkan nilai-nilai karakter yang akan dikembangkan dalam pembelajaran, namun tidak tercermin antara nilai karakter dengan kegiatan atau langkah-langkah pembelajaran. Dalam kasus ini, nilai-nilai karakter yang dicamtumkan dalam pembelajaran terkesan sebagai pajangan. Hal ini sejalan dengan temuan Japa dan Sujendra (2016) yang menemukan bahwa ratarata guru telah berupaya menerapkan pendidikan karakter pada mata pelajaran namun pendidikan karakter tersebut tidak terintegrasi secara baik dan menyeluruh dalam perangkat pembelajaran yang digunakan, sehingga implementasi pendidikan karakter dalam proses pembelajarannya tidak tampak.

Hasil penyekoran RPP secara menyeluruh diperoleh skor rata-rata sebesar 78 dengan tingkat persentase sebesar $65 \%$ yang berada dalam kategori cukup. Berdasarkan wawancara ditemukan bahwa kurang terampilnya menyusun RPP disebabkan karena pemahaman guru terkait konsepsi pembelajaran tematik Kurikulum 2013 yang masih kurang. Hal ini menjadi rasional mengingat pembelajaran tematik sangatlah berbeda dengan pembelajaran parsial (pelajaran terpisah). Permasalahan ini disebabkan karena sosialisasi Kurikulum 2013 yang selama ini diberikan kepada guru-guru hanya terbatas pada tatanan konsepsi atau teoritis. Hasil wawancara menunjukkan bahwa guru memerlukan pendampingan dalam bentuk praktik atau pengawasan pembelajaran dari dinas maupun universitas.

Hasil pengamatan pembelajaran diperoleh bahwa guru sudah melaksanakan pembelajaran dengan baik akan tetapi terkait komponen penguatan materi dengan cakupan nilai karakter masih belum tampak. Guru sudah melaksanakan pendidikan karakter namun dalam bentuk ativitas dan keteladanan seperti mengajak berdoa untuk mengembangkan nilai religius dan beberapa kegiatan untuk mengembangkan kedisiplinan. Temuan lain menunjukkan bahwa dari nilai-nilai karakter yang termuat dalam RPP, tidak semuanya muncul dalam pembelajaran yang dilaksanakan. Materi-materi tidak dilakukan pemodifikasian seperti contohnya dalam muatan matematika, guru sudah memberikan proses pemecahan masalah melalui soal kontekstual akan tetapi guru berhenti setelah siswa berhasil memperoleh jawaban yang benar. Seharusnya, soal tersebut bisa dikembangkan dengan menambahkan pertanyaan-pertanyaan lain yang berhubungan dangan karakter.

Temuan-temuan tersebut di atas menunjukkan bahwa terkait pelaksanaan pendidikan karakter dalam pembelajaran tematik Kurikulum 2013, guru sudah menerapkan strategi pelaksanaan pendidikan karakter namun belum optimal. Dalam hal ini, guru lebih banyak melaksanakan pendidikan karakter secara tidak langsung artinya guru menjadi contoh atau menjadi teladan bagi siswa dengan cara bertindak sesuai etika dan karakter.

Sudrajat (2011) menyatakan bahwa dalam menerapkan pendidikan karakter dapat dilakukan dengan empat cara yaitu: (1) pembelajaran (teaching), yaitu setiap nilai yang akan ditanamkan atau dipraktikkan tersebut harus senantiasa disampaikan oleh para guru melalui pembelajaran langsung (sebagai mata pelajaan) atau mengintegrasikannya ke dalam setiap mata pelajaran, (2) keteladanan (modeling), adalah guru meneladankan secara teratur dan berksinambungan, (3) penguatan (reinforcing), memberikan dukungan berupa poster atau spanduk yang mengarah dan memberikan dukungan bagi terbentuknya suasana kehidupan sekolah yang berkarakter terpuji, dan (4) pembiasaan (habituating) dapat dilakukan di sekolah dengan berbagai cara dan menyangkut banyak hal seperti disiplin waktu, etika berpakaian, etika pergaulan, perlakuan siswa terhadap karyawan, guru, dan pimpinan, dan sebaliknya. Efektivitas pelaksanaan pendidikan karakter di sekolah sangat ditentukan oleh keempat cara tersebut.

Hal lain yang penting dalam pelaksanaan pendidikan karakter yaitu konsitensi dari guru itu sendiri. Maksudnya adalah guru secara konsiten mengembangkan nilai-nilai karakter di setiap pertemuan. Hal ini sesuai dengan yang dikemukakan Rachman (2010) yang menyatakan bahwa pendidikan karakter harus dijalankan dengan konsisten, kontinu dan konsekuen, sebagai suatu upaya sadar dan terencana untuk menumbuhkan dan memahatkan karakter-karakter pada diri siswa

\section{Simpulan dan Saran}

Hasil penelitian menunjukkan bahwa guru sudah memahami konsepsi pendidikan karakter akan tetapi belum secara mendetail terkait deksripsi 18 nilai karakter yang bisa dikembangkan dalam pembelajaran. Terkait RPP pembelajaran tematik Kurikulum 2013 yang dirancang, nilai-nilai karakter yang dipilih untuk dikembangkan dalam pembelajaran belum terlihat dalam langkah-langkah pembelajaran. Dalam tahap pelaksanaan pembelajaran, nilai-nilai karakter yang tercantum dalam RPP belum terimplementasi dengan baik. Guru lebih banyak memberikan keteladanan kepada siswa.

Berdasarkan temuan-temuan dalam penelitian, beberapa saran diajukan diantaranya: 1) perlu diberikan pendalaman materi pembelajaran tematik dan pendidikan karakter berserta pendampingannya bagi guru-guru, 2) para guru hendaknya lebih aktif dalam mencari referensi maupun melakukan kerjasama dengan para dosen khususnya di Jurusan PGSD Undiksha dalam hal penguatan pembelajaran 
tematik Kurikulum 2013, dan 3) perlu dilakukan penelitian lanjutan untuk membuat perangkat pembelajaran tematik terintegrasi yang validuntuk guru di sekolah dasar.

\section{Daftar Rujukan}

Adisusilo, S. (2011). Pembelajaran Nilai-Karakter. Konstruktivisme dan VCT Sebagai Inovasi Pendekatan Pembelajaran Afektif. Jakarta: PT RajaGrafindo Persada.

El-mubarok, Z. (2008). Membumikan Pendidikan Nilai, Mengumpulkan yang Terserak, Menyambung yang Terputus dan Menyatukan yang Tercerai. Bandung: Alfabeta.

Hadi, R. (2015). The Integration of Character Values in the Teaching of Economics: A Case of Selected High Schools in Banjarmasin. International Education Studies, Vol. 8, No. 7.

Japa, I G. N. \& Diputra, K. S. (2017). Improving Teachers' Ability in Integrating Character Education into Mathematics Subject Matter Through Lesson Study in Group V Sukasada Sub-district. Proceeding ICLS7th, 81-88.

Kemdiknas. (2010). Pengembangan Pendidikan Budaya dan Karakter Bangsa. Jakarta: Puskur-Balitbang Kemdiknas.

Rachman, A. (2010). Urgensi Pendidikan Karakter dalam Membangun Bangsa.Makalah pada Seminar Nasional Pendidikan Nilai-Karakter, 28 Juli 2010, Sekolah Pascasarjana UPI, Bandung.

Sudrajat, A. (2011). Mengapa Pendidikan Karakter?. Jurnal Pendidikan Karakter, Vol. 1, No. 1

Undang-undang Republik Indonesia No. 20 tentang Sistem Pendidikan Nasional. 2003. Jakarta: Depdiknas.

Peraturan Menteri Pendidikan dan Kebudayaan Nomor 57 Tahun 2014. Jakarta: Kemendikbud.. 